\title{
Impact of Brand Image on Purchasing Decision on Mineral Water Product "Amidis" (Case Study on Bintang Trading Company)
}

\author{
Bob Foster \\ Economics Faculty of University informatics and Business of Indonesia \\ Jl. Purnawarman 36B \\ unibi.ac.id
}

Abstract: This study aims to determine if there is impact between the brand image of mineral water "Amidis" on purchasing decisions. The object of research conducted at the trading company by using accidental sampling method by distributing questionnaires to consumers and prospective buyers of mineral water. Then from the responses of the respondents, the data was processed by using SPSS 20.0. Brand image consists of three variables: the attributes, benefits and attitudes. Where the results of the research show that the attitude has the greater impact on purchasing decisions than the variable attributes and benefits. Overall, the impact of brand image on purchasing decisions only $7 \%$ means that the consumer purchasing decisions are more influenced by other variables than the brand image alone.

Keywords: Brand Image, Purchasing Decision

\section{INTRODUCTION}

The rapid development of the business world, followed by high levels of competition between companies requires management companies, especially large trading company to be able to produce products which have a good brand image in other to survive and to continue to develop their business. In modern marketing system, a product is not only important to be given a brand but also be able to give a good impression on consumers mind so that consumers ultimately decide to make a purchasing

In making a purchasing decision, consumers will go through several stages as proposed Philip Kotler (2003: 224) including the stage of information search and alternatives evaluation. It means that consumers faced with several options that will be considered in making purchasing decisions. This is where the brand image plays an important role in influencing the decision-making process.

Therefore the company should not ignore the brand image of their products because the brand image is a company identity that can be known by customer. So company must think about the right strategy to introduce the products to be offered in the market so that it can influence consumers to buy products or services offered by the company. The strategies can be by arranging and creating a brand image of the products or services offered to consumers.

The role of brand becomes very important since it is the product attribute in communicating the product to consumers about quality of products, characteristic, and other attributes related to these products. Consumers will keep to remember the brand if the brand quality is deemed good on consumers mind and will ultimately affect the consumer in making a product purchase action. 
It is important for company to know how the company's brand position in the minds of consumers and then develop strategies to continue to improve and strengthen the brand image that could ultimately result in consumers loyalty to the brand. In contrast, the bad brand strategy will not will not be able to influence the purchasing decisions of consumers. This means that brand strategy that could not produce a good brand image, will not be able to influence the purchasing decisions of consumers. From the description, it can be revealed the importance of brand image for the company's profits of which can influence consumer purchasing decisions and create consumer loyalty as expressed also in research Budianto Antony et al (2013).

Based on the background above, the researcher is interested in conducting research about the impact of brand image on purchasing decisions. The products chosen for research is limited to mineral water products "Amidis". Therefore, researchers will conduct a study entitled "Impact of Brand Image on Purchasing Decision on Mineral Water Products "Amidis"”."

\section{THEORETICAL FRAMEWORK}

\subsection{Brand}

Brand is one of important factor in marketing activities because introducing activities and offering products or services can not be separated from dependable brand. Besides, the brand is also an important attribute of a product and a brand identity to differentiate the company's products with other products that produced by competitors. By giving the brand on a product, it makes the product easier to be recognized by consumers.

Managing the brand means creating an association to the brand so that a product or brand can be embedded in the customer mind as a result of the communication that has been done. Plugging a product or brand into customer mind is an attempting in other to make the product or brand has a strategic position in the market so it can compete stronger in the increasingly tight competition area. In order to provide a clearer description of the meaning of the brand, the following are some understanding of the brand, according to experts.

Brand according to America Marketing Association (Kotler, 2009:258) :"A brand is a term, design, name, symbol or any other features that distinguish one company's product to the others." Broadly speaking, the Brand is a name, term, symbol, design or a combination of those things are intended to identify the goods or services by an individual or a group and as well as to differentiate their products with other competitors' products.

\subsection{Brand Image}

It is explained by Business Dictionary in Neupane (2015 : 10) "Brand image is a unique set of associations in the mind of customers regarding what a brand stand for and the implied promises the brand makes. This means that the brand image is a unique set of associations in the minds of customers about what brands stand for.

Further about the Brand image is defined by Kotler and Keller in Heriati \& Septi $(2012: 174)$ "The Perceptions and belief held by customers, as reflected in the associations held in consumer memory".This indicates that perceptions and beliefs held by the customer as the association is reflected in the memory of consumers.

Another suggestion is explained by Tjiptono (2005: 49) stated that "brand image is a description of the association and the trust of consumers towards a particular brand." As Kotler (2009: 260) perceives the brand image as a process of someone's choice, organize and interpret information inputs to create a meaningful description. While Kotler in Armstrong (2001: 225) defines brand image as a set of consumer trust about the certain brand. 
Based on some definition about the meaning of some the above theories, brand image can be interpreted as a description which obtained by the consumer or the perception which formed on consumers of a certain brand, as also stated by Mowen in Widiyaningsih (2013) that the brand image is a set of brand associations which formed in the minds of consumers.

Consumer perception of a brand also means that consumers will assess whether a brand is considered more superior or inferior compared to other brands such as the functional aspects, durability or it might also emotionally. With a positive image of a brand, the purchase will be more likely to be carried by consumers Setiadi (2003: 180). Consumers could also often to buy products with famous brand because they feel more comfortable (emotional) with things that are already known. Stated in Widiyaningsih Aaker (2013

\subsection{Brand Indicator}

Kotler and Keller in Risda (2014) explained that the brand image can be considered as a kind of associations that arise in the minds of consumers when considering a particular brand. The association can simply appear in the form of a certain thought or image that is associated with a brand, it is same as when someone is thinking about other people. The kind of brand associations include the attributes, benefits and attitudes.

Further, Davis (2000: 53) explained that the brand image has two elements, they are Brand Personality and Brand Associations. While Joseph Plummer in Aaker (1991: 139) described the the brand image with the three components, namely: Product Attributes which are related to brands such as packaging, product content, pricing, taste, etc; Consumer Benefits which are the usefulness of the products of the brand and the Brand Personality which is the personality association of a brand

But Fransisca Paramitasari Musay (2013) in the journal mentioned the component of the brand image according to Biel (1992) consists of the company image, user image and product image. Biel (1992) in Karina (2012: 86) stated that brand image as "A cluster of attributes and associations that connect consumers to the brand name". It is described by another reference where brand image is a group of attributes and associations where consumer linked to the brand name.

According to Shimp (2003: 592) in Rizan et al (2012: 5) expressed "There are three parts in the measurement of brand image." Further explained related to the first part is the attribute. Shimp in Rizan et al (2012:5) stated that the "Attributes are characteristics or the various aspects of the advertised brand. Attributes are also divided into two parts, they are things that are not related to the product (example: price, packaging, users, and user image) and things related to the product (example: color, size, design).

Then the second part of the measurement of brand image according to Shimp in Rizan et al (2012: 5) is the benefits which is described "The benefits are divided into three parts, namely functional, symbolic, and experience." This understanding is described as follows:

1. Functional, is the benefits that seeks to provide a solution for consumption issues or potential problems that might be experienced by consumers, by assuming that a brand has a specific benefits that can solve the problem

2. Symbolic, which is directed to the consumers wants in an effort to improve themselves, appreciated as a member of a group, affiliates, and a sense of belonging.

3. The experience, in which the consumer is a representation of their desire for a product that can give a sense of fun, diversity, and cognitive stimulation. Finally, the third part of measuring brand image according to Shimp is the whole evaluation, value or subjective interests where customers add it to the consumption results.

Volume 2

Page 3 
Furthermore, the latest in Rizan Shimp et al (2012: 5) revealed the third part of measuring brand image according to Shimp is the whole evaluation, that is value or subjective interests where by customers add it to consumption results. Therefore, based on some references related to brand indicators, the author considered indicators of the attributes, benefits and attitudes that are built based on the reference of Kotler and Keller in joseph (2014), Plummer in Aaker (1991: 139) and Shimp in Rizan et al (2012: 5 ) in building the construct which is adjusted to the research that will be examined so that these three indicators is expected to explain the purpose of this study.

\subsection{Purchasing Decision}

When you make a purchasing, consumers are faced with some choices of several existing products before deciding to make a purchasing. Furthermore, purchasing decision according to Schiffman, Kanuk (2004: 547) is "the election of two or more alternative purchasing decision, it means that someone can make a decision, it should be available some alternative options. So, the outlines is the decision to purchase can lead to how the process in the decision was made.

Furthermore, other references described by Peter and James (2004: 48) in Wibowo \& Karimah (2012: 6) the purchasing decision is the process by which consumers make the decision to purchase a variety of products and brands that began with the introduction of needs, information research, evaluation of information, making purchase and then evaluate the decision after purchasing. There are five stages of the process level model in consumer decision purchasing: problem introduction, information search, alternatives evaluation, purchasing decision and post-purchasing behavior.

According to Kotler and Keller (2009: 184), the specific purchasing decision process consists of these sequence steps as follows: introduction of the problems, needs, information search, alternatives evaluation, purchasing decision and post-purchase behavior. As for Peter and Olson in the Fransisca's journal (2013) describes the purchasing decision as the process of integration that combines the knowledge to evaluate the behavior of two or more alternatives and choose the one of them. So that the process of consumer purchasing decision making does not stand alone but influenced by several factors as stated by Kotler (2007); cultural factors, social, personal and psychology of the buyer.

Brand image has an important position in influencing the purchasing decisions by consumers, because one of the decisions in the structure of the purchasing is the decision regarding the choice of brand. Because when buying a product, consumers do not just buy a product as a commodity, but rather buy a symbolic value contained in the brand. Consumers will be easier to identify and are not confused by the brand that has been embedded in the of consumer's minds.

Brand image will also facilitate consumers in distinguishing the quality of their products with other competitors' products, and the brand is also very instrumental in helping the consumer perception of product quality. This means the perception that has been formed by the brand could influence the purchasing decisions by consumers.

\subsection{Indicator of Purchasing Decision}

Explained by Wibowo \& Karimah (2012: 6) there are five model stages of consumer purchasing decision process: introduction of problems, information search, alternatives evaluation, purchase decision and post-purchasing behavior. In this study the authors use Indicator of Purchasing Decision Kotler and Armstrong in Wibowo \& 
Karimah (2012: 6) as a reference for this research reference. As the explanation, here are some explanations are described as follows. According to Kotler and Armstrong, the five stages are:

1. Problem Introduction. Problem introduction is a situation where there is a difference between the desired situation to the actual circumstances occurred, Sumarwan $(2004 ; 234)$. According to Fadli and Inneke (2008) this indicator can be measured by: Fulfilling needs, commodity products, and product quality.

2. Search Information According to Sumarwan (2004; 294), information search started when a consumer think that the decision could be met by purchasing and consuming a product. According to Fadli and Inneke (2008), this indicator can be measured through: Barriers to information, observation products and media promotion of the product.

3. Alternatives Evaluation. Alternatives Evaluation is the process of evaluating the chosen alternative product or brand and select them according to the customer wants. Sumarwan(2004;294). According to Fadli and Inneke (2008) this indicator can be measured through: product prestige value, the purchase price in general and quality standards.

4. Purchasing Decision. The strong self-confidence in consumers or customer which is the trust where by the decisions towards taken purchasing is correct (Astuti and Cahyadi 2007 in Amira Tria Hanin, 2011). According to Fadli and Inneke (2008) this indicator can be measured through: The influence of others, desire and ability of consumers and intensity of consumer purchasing.

5. Consumers Post-Purchasing Behavior will evaluate the product that had been bought, whether it is satisfactory or not, if it is satisfactory and in accordance with consumers' expectations then there is a possibility they will come back to buy the product. According to Fadli and Inneke (2008), the indicator can be measured through: An assessment of the quality, recommendation to others as well as an assessment of the product.

\subsection{Research Framework and Research Hypotheses}

To see whether there is any impact on the brand image of the product purchasing decisions on mineral water "Amidis", it can be described in the following framework:

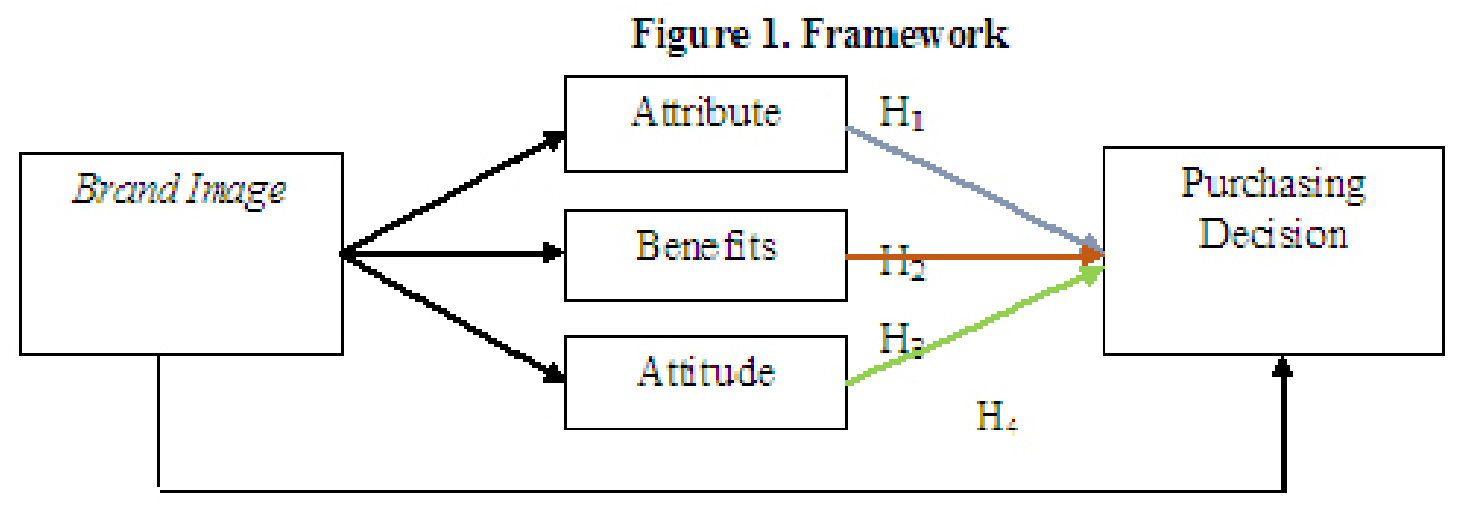

Fig 1. Framework 
The relevance and impact of brand image on decision has been researched by some researcher, they are Fransisca (2013) who conducted a survey on Consumer KFC Kawi Malang showed that brand image is consisted of the corporate image, the image of the user, and product image simultaneously has a significant impact on purchasing decisions, but the variable of users image positively effect but not significantly. As for Alfie (2012), which examined the impact of brand image on purchasing decision making of Toyota Innova at PT. Hadji Kalla branch Polman showed that the variables of brand image that consists of excellence brand association, strength of brand association, and uniqueness of brand associations have the significant impact on the purchasing decision.

Likewise, the previous studies conducted by Ria Fitriani (2008), who examined the impact of brand image ULTRAMILK on consumer purchasing decision process show that the brand image has a significant positive relationship on consumer purchasing decisions. Differences in selecting the indicators of brand image encourage the researchers to choose another indicators to find out whether it will also generate the similar results to the previous studies. In this case the researchers chose the indicator of attributes, benefits and consumers attitudes.

The formulation of the research hypothesis is also taken from the previous research results are as follows:

H1: Attributes will influence the purchasing decisions of mineral water "Amidis".

$\mathrm{H} 2$ : The Benefits of influence on purchasing decisions of mineral water "Amidis".

H3: Attitudes will influence the purchasing decisions of mineral water "Amidis".

H4: Brand Image influence on purchase decisions mineral water "Amidis".

\section{RESEARCH METHOD}

\subsection{Type of Research}

In this study, the researcher uses the quantitative research methods by using the type of descriptive research.

\subsection{Population and Sample}

The population in this study are all consumers who live in Bandung city. In this study the number of samples that had been used is 117 respondents.

\subsection{Sampling Technique}

Accidental sampling technique is sampling technique based on anyone who incidentally meet with researchers in research location will be used as a sample if they are considered suitable as a data source.

\subsection{Data Analysis}

1. Descriptive Analysis

2. Multiple Linear Regression Analysis

3. Hypothesis test

a) $t$ - Test

b) F- Test 


\section{RESULT}

The number of sample in this study is 117 respondent.

Table 1. Characteristics of Respondents

\begin{tabular}{|l|l|c|}
\hline \multicolumn{1}{|c|}{ Items } & \multicolumn{1}{|c|}{ Category } & $\%$ \\
\hline \multirow{4}{*}{ Gender } & Male & $48.7 \%$ \\
\cline { 2 - 3 } & Female & $51.3 \%$ \\
\hline \multirow{3}{*}{ Age } & $21-30$ & $62.3 \%$ \\
\cline { 2 - 3 } & $31-40$ & $18.8 \%$ \\
\cline { 2 - 3 } & $41-50$ & $7.6 \%$ \\
\cline { 2 - 3 } & $>51$ & $11.1 \%$ \\
\hline \multirow{5}{*}{ Job } & Government Employees & $24 \%$ \\
\cline { 2 - 3 } & Private employee & $40 \%$ \\
\cline { 2 - 3 } & entrepreneur & $25.2 \%$ \\
\cline { 2 - 3 } & Student & $7.8 \%$ \\
\cline { 2 - 3 } & Others & $3 \%$ \\
\hline
\end{tabular}

Source: Primary Data (Processed) 2016

\section{Impact of Brand Image on Purchasing Decision}

This testing was done with one dependent variable and one independent variable that consists of three sub independent variables. This testing was conducted by using SPSS to find out the independent variables that affect the dependent variable. This testing also aims to find out how much the influence of brand image (attributes, benefits and attitudes) on purchasing

Table 2. Model Summary of Brand Image Variable (Attribute, benefit and attitude)

Model Summary

\begin{tabular}{|c|c|c|c|c|}
\hline Model & $\mathrm{R}$ & R Square & Adjusted R Square & $\begin{array}{c}\text { Std. Error of the } \\
\text { Estimate }\end{array}$ \\
\hline 1 & $.265 \mathrm{a}$ & .070 & .046 & 3.68319 \\
\hline--
\end{tabular}

Predictors: (Constant), Average Attitude, Average_Benefit, Average_Attribute

Source : Result of SPSS 20, 2016

Table 3. ANOVA Brand Image Variable

\begin{tabular}{|c|l|l|l|l|l|l|}
\hline \multicolumn{2}{|l|}{ Model } & \multicolumn{1}{|c|}{ Sum of Squares } & \multicolumn{1}{|c|}{ df } & \multicolumn{1}{|c|}{ Mean Square } & F & S1g \\
\hline 1. & Regression & 17.302 & 3 & 5.767 & 24.768 & 0.000 \\
& Residual Total & 25.847 & 111 & 0.233 & & \\
& 43.150 & 114 & & & \\
& & & & & & \\
\hline
\end{tabular}

a. Predictors: (Constant), attitude, attribute, benefit

b. Dependent variable: Interest

Source : Result SPSS 20, 2016

Volume 2 
From the ANOVA test, it can be known that $\mathrm{F}$ count is 24.768 with significant numbers of $0,000<0: 05$ therefore Ho rejected and Ha accepted. This means that the whole brand image positively influence on the purchasing decision.

Table 4. Variable Coefficient of Attribute. Benefit and Attitude

Coefficients $^{\mathrm{a}}$

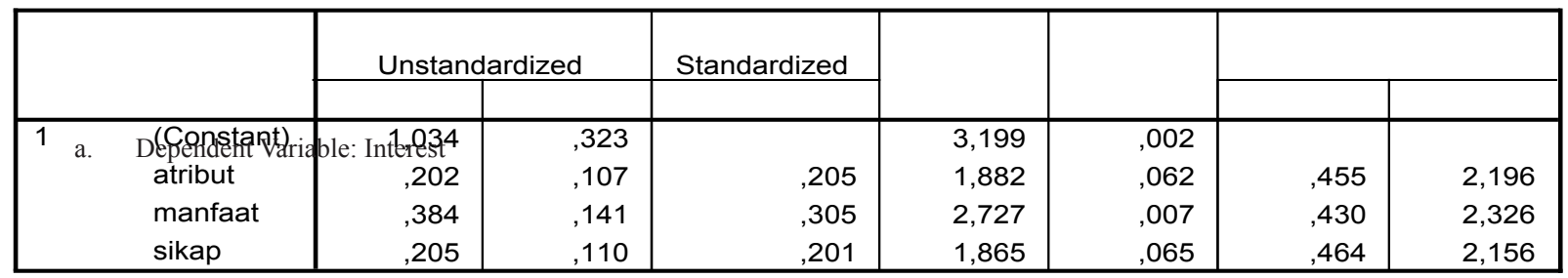

a.

Source : Result of SPSS 20, 2016

Output Analysis:

Based on the coefficient table above, it is described the regression equation:

$\mathrm{Y}=b+b 1 \mathrm{X} 1+b 2 \mathrm{X} 2+b 3 \mathrm{X} 3$

$\mathrm{Y}=1.034+0.202 \mathrm{X} 1+0.384 \mathrm{X} 2+0.205 \mathrm{X} 3$

Where:

Y = Purchasing Decision on Mineral Water "AMidis"

$\mathrm{X} 1=$ Attribute

$\mathrm{X} 2=$ Benefit

X3 = Attitude

Based on the explanation above, the significant impact is only "benefit" variable, the reason is because the sig is smaller than 0.05 whereas attribute and attitude have no significant influence.

Hypothesis Testing

The result of hypothesis testing based on the tables above, are as follow

Hypothesis 1

Ho:p $=0$ : Attribute is not influence positively on purchasing decision

Hi:p $\neq 0$ : Attribute influence is positively on purchasing decision

a. Significance level $\alpha=0.05$

b. Acceptance criteria : Ho rejected if $\alpha<0.05$

c. $\alpha$ value which obtained from regression is 0.063

d. This result shows that Ho is accepted and Ha rejected, at the significance level $\alpha=0: 05$. This means that the attributes of the mineral water "Amidis" has no effect on the purchasing decision.

The conclusion that can be drawn from hypothesis 1 regarding to the exist of attributes influencing mineral 
water "Amidis" on purchasing decisions, proves that the attribute of mineral water "Amidis" does not give the significant results on purchasing decision from the consumer. In other words, there is no positive effect of attribute mineral water "Amidis" on the purchasing decision.

Hypothesis 2

a. Ho:p=0 : The benefits of mineral water "Amidis" is not positively influence on purchasing decisions.

b. Hi:p $\neq 0$ : The benefits of mineral water "Amidis" is positively influence on purchasing decisions.

The significance level $\alpha=0.05$

c. Acceptance criteria : Ho rejected if $\alpha<0.05$

d. $\alpha$ value which obtained from regression is 0,007

This result shows that Ho is rejected and Ha accepted, at the significance level $\alpha=0: 05$. This means that the benefits of mineral water "Amidis" is positively influence on purchasing decision.

The conclusion that can be drawn from hypothesis 2 regarding to the positive influence of benefit on mineral water "Amidis" on purchasing decisions, proves that the benefit of mineral water "Amidis" gives the significant results on purchasing decision from the consumer.

\section{Hypothesis 3}

a. Ho:p=0 : Attitude of mineral water "Amidis" is not positively influence on purchasing decision

b. Hi: $p \neq 0$ : Attitude of mineral water "Amidis" is positively influence on purchasing decision The significance level $\alpha=0.05$

c. Acceptance criteria : Ho rejected if $\alpha<0.05$

d. $\alpha$ value which obtained from regression is 0,065

e. This result shows that Ho accepted and Ha rejected, at the significance level $\alpha=0.05$.

It means that the attitude of mineral water "Amidis" does not positively influence on purchasing decision.

The conclusion that can be drawn from hypothesis 3 regarding to the positive influence of attitude on mineral water "Amidis" on purchasing decisions, proves that attitude does not give the significant results on purchasing decision. In other words, there is no positive effect of attitude mineral water "Amidis" on the purchasing decision.

\section{Hipotesis 4}

a. Ho:p=0 : Brand Image of mineral water "Amidis" is not positively influence on purchasing decision

b. Hi: $p \neq 0$ : Brand Image of mineral water "Amidis" is positively influence on purchasing decision The significance level $\alpha=0.05$

c. Acceptance criteria : Ho rejected if $\alpha<0.05$

d. $\alpha$ value which obtained from regression is 0,000

e. This result shows that Ho is rejected and Ha accepted, at the significance level $\alpha=0: 05$. This means that the brand image of mineral water "Amidis" is positively influence on purchasing decision 
The conclusion that can be drawn from hypothesis 4 regarding to the positive influence of brand image on mineral water "Amidis" on purchasing decisions, proves that the brand image of mineral water "Amidis" gives the significant results on purchasing decision from the consumer.

\section{CONCLUSION AND SUGGESTION}

\subsection{Conclusion}

Based on the research results, it can be concluded:

1. Attributes is not positively influence on purchasing decisions among buyers and potential buyers of mineral water "Amidis".

2. Benefit is not positively influence on purchasing decisions among buyers and potential buyers of mineral water "Amidis".

3. Attitude is not positively influence on purchasing decisions among buyers and potential buyers of mineral water "Amidis".

4. Brand image of mineral water "Amidis" is positively influence on purchasing decisions among buyers and potential buyers of mineral water "Amidis" by 7\% contributing and the rest around 93\% is influenced by other factors which is not included in this research

\subsection{Suggestion}

Based on the conclusion, the researchers can give the following suggestions:

1. Based on the results of research which shows that the attribute and attitude of mineral water "Amidis" do not affect the purchasing decision, then those two things should be a concern for manufacturers improved.

2. Knowing that the contribution of the brand image on purchasing decision which is only $7 \%$, then it means that there are other variables that have the greater influence on purchasing decisions. It is suggested for other researchers to investigate other greater variables that may influence on purchasing decisions of mineral water "Amidis".

\section{REFERENCES}

Aaker, J.L. 1997. Dimensions of Brand Personality, Journal of Marketing Research, Vol. 34 No. 3, pp. 347-56

Alfian, B. 2012. Pengaruh Citra Merek (Brand Image) Terhadap Pengambilan Keputusan Pembelian Mobil Toyota Kidjang Inova Pada PT. Hadji Kalla Cabang Polman Makasar. Universitas Hasanuddin.

Budianto Antony, dkk. 2013. Brand Image Sebagai Aset Penting Bagi Perusahaan. BINUS University, Jakarta.

Fadli dan Inneke Qamariah. (2008). Analisis Pengaruh Faktor-Faktor Ekuitas Merek Sepeda Motor Merek Honda Terhadap Keputusan Pembelian. (1)2. 48-58

Fitriani,Ria,Nita.(2013). Analisis Kinerja Keuangan Berdasarkan Rasio Profitabilitas, solvabilitas dan Likuiditas pada Perum Pegadaian Cabang Ponorogo. Universitas Muhammadiyah Ponorogo.

Fransisca Paramitasari Musay. 2013. Vol 3, No 2. Pengaruh Brand Image Terhadap Keputusan Pembelian, Jurnal Administrasi Bisnis. Universitas Brawijaya.

Heriyati, P. \& Septi. 4(2), 171-205. Journal of Business Strategy and Execution.

Karina Ritzky, dkk. 2014. Pengaruh Brand Identity Terhadap Timbulnya Brand Preference Dan Repurchase Intention Pada Merek Toyota. Jurnal Manajemen Pemasaran Petra. 
American Research Journal of Humanities and Social Sciences (ARJHSS)

Kaswengi Joseph. 2014. Store image dimensions and brand equity: the moderating role of demographic characteristics. www.marketing-trends-congress.com

Keller Kevin, Kotler Philip, dkk. 2009. Marketing. Pearson. Prentice Hall. England. Kotler, Gary Armstrong, 2001, Principles of Marketing. $8^{\text {th }}$ Edition.Prentice Hall, New Jersey.

Kotler Philip,2 003, Marketing Management $12^{\text {th }}$ Edition. Pearson, New Jersey

Kotler dan Keller, 2007. Manajemen Pemasaran, Edisi 12, Jilid 1, PT. Indeks, Jakarta.

Neupane. 2015. Vol 2, No 1. International Journal of Social Sciences and Management.

Rizan M., Saidani, B., dan Sari Y. 2012. Pengaruh Brand Image Dan Brand Trust Terhadap Brand Loyalty Teh Botol Sosro. Jurnal Riset Manajemen Sains Indonesia (JRMSI), Vol. 3 (1), 1-17.

Septiani Risda. 2014. Pengaruh Brand Image, Kualitas Produk Terhadap Brand Preference Dan Implikasinya Terhadap Minat Loyalitas. Universitas Diponegoro. Semarang.

Setiadi, Nugroho J. 2003. Perilaku Konsumen: Konsep dan Implikasi untuk Strategi dan Penelitian Pemasaran. Jakarta: Prenada Media.

Tjiptono, Fandy, dkk. (2005). Marketing Scale. ANDI. Yogyakarta.

Tria Hanin Amira. 2011. Analisis Pengaruh Ekuitas Merek Terhadap Keputusan Pembelian Handphone Blackberry. Universitas Diponegoro. Semarang.

Ujang Sumarwan. 2004. Perilaku Konsumen Teori Dan Penerapannya Dalam Pemasaran, Bogor, Ghalia Indonesia.

Wibowo, Setyo Ferry \& Maya Puspita Karimah. (2012). Pengaruh iklan televisi dan harga terhadap keputusan pembelian sabun lux. Jurnal Riset Manajemen Sains Indonesia. Jakarta. Vol 3,No. 1.

Widiyaningsih Yulia Arisnani, Dharmesti Theresia Rasika Seta. 2015. Pengaruh Citra Merek Pada Niat Perpindahan Merek Produk Pewarna Bibir Oleh Pengguna Yang Memiliki Kepuasan Dan Karakteristik Yang Berbeda-beda. Universitas Gadjah Mada.

Citation: Bob Foster, Impact of Brand Image on Purchasing Decision on Mineral Water Product "Amidis". (Case Study on Bintang Trading Company), American Research Journal of Humanities and Social Sciences, Volume 2, 2016; pp:1-11

Copyright (c) 2016 Bob Foster, This is an open access article distributed under the Creative Commons Attribution License, which permits unrestricted use, distribution, and reproduction in any medium, provided the original work is properly cited. 